\title{
Better outlook next decade for young West German researchers
}

\section{Bonn}

Ask a young West German academic who will pay his salary next year, and he is likely to look to the heavens. The job situation in many fields has been bleak. But according to the Wissenschaftsrat, West Germany's influential science council, that will all change in the 1990s.

Wissenschaftsrat's chairman, Kurt Kochsiek, held a press conference here on 2 February to "give courage" to young researchers considering careers in academic life. Kochsiek cited a new council survey which showed that the turnover of tenured professors in most university faculties will return to normal levels of 4-5 per cent a year by the mid-1990s. Turnover has recently been less than one per cent a year in some areas.

But Kochsiek was the first to acknowledge that the calculations depend on the number of tenured positions, now about 16,000 , remaining stable. Hubert Markl, president of the Deutsche Forschungsgemeinschaft (DFG), was quick to agree. The DFG funds much of the basic research at universities in West Germany.

Kochsiek said that there is already a healthy turnover in some fields, such as engineering, computer science and Protestant theology. By 1995, there will be good opportunities in veterinary sciences, agricultural sciences and architecture. Humanities and social sciences will remain problem areas.

The Wissenschaftsrat did not call for the creation of any new funding programmes to keep qualified young people in the universities until positions become available. There are already a number of such programmes. The Heisenberg programme, for example, gives multi-year support to as many as 60 young researchers each year who have already completed a Habilitation.

But Markl added that disgruntled academics are poisoning the atmosphere. "It's tremendously discouraging when the students see someone who has worked hard but still doesn't get a job".

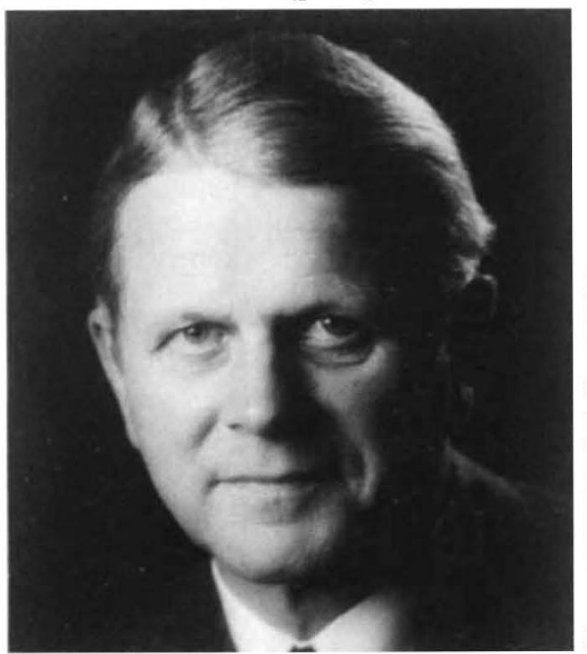

Kurt Kochsiek - looking to a brighter future.

An even bigger problem will be the threat of cuts in universities as the number of students starts to drop in the 1990s. Some of the Länder, which run the universities, have already begun to cut back despite overflowing laboratories and lecture halls. In Markl's view, even small cuts would be "disproportionately damaging" because of the negative message they would send to good students.

Steven Dickman

\section{Indian ballistic missiles on the way}

\section{New Delhi}

INDIA successfully test-fired its homeproduced surface-to-surface missile Prithvi that can deliver a one-tonne warhead on a target 250 kilometres away in less than 150 seconds. It is the forerunner of the intermediate-range ballistic missile (IRBM) that India is likely to test later this year.

Announcing Prithvi's launch from Sriharikota base, Prime Minister Rajiv Gandhi said that it belongs to a class of missiles produced only by the United States, Soviet Union, France and China. He said it was designed and built by scientists at the Defence Research Development Organisation (DRDO) and "no foreign knowhow or collaboration was involved".

Prithvi is powered by two gymbal-mounted engines burning high-specific-impulse liquid propellant. It is designed to leave the ground in 10 seconds after command, and its entire flight is controlled by a strapdown gyro system coupled to an on-board computer. According to a DRDO spokesman, it can carry "different types of payload" and compared to other missiles of this class, "has the best warhead-to-weight ratio." Describing the test flight as "far beyond expectation," he said telemetry data showed a bullseye hit, with circular error of probability (CER) almost zero.

Prithvi is the second missile to come out of DRDO's five-year old integrated guided missile development programme. Trishul, a short-range $(10 \mathrm{~km})$ surface-to-air missile developed last year is soon to enter production. The ultimate aim is to develop an intercontinental ballistic missile.

The missile programme is no doubt worrying Pakistan where the latest launch is interpreted as Indian preparation for a nuclear delivery system. K.S. Jayaraman

\section{New money for Caltech}

\section{Pasadena}

THE California Institute of Technology (Caltech) is poised to give a team headed by Leroy Hood a spacious new facility for developing advanced DNA sequencing technology and exploring the uses of computer chips and neural networks for the analysis of sequence data. Such largesse is made possible by the new Beckman Institute to be located on the Caltech campus, where space and money will be available for exploratory research projects and interdisciplinary technology development.

The institute, financed by a $\$ 50$ million grant from the Arnold and Mabel Beckman Foundation and $\$ 10$ million in matching funds raised by Caltech, will generate no new faculty positions, but will instead consist of flexible space where existing faculty can set up 'resource centres' for technology development at the interfaces of chemistry, engineering, biology and medicine.

Jokingly dubbed "The Beckman Institute for Harebrained Research" by its director, Caltech chemistry professor Harry Gray, the institute will also provide small $(\$ 50,000-\$ 100,000)$ start-up grants for interesting high-risk projects that may not be immediately fundable by government agencies but which promise important advances should they succeed.

Gray expects there to be four or five resource centres in the institute at any one time, each with 10-50 research staff and $5,000-10,000$ square feet of space. Caltech plans to spend $\$ 25$ million on the 140,000 square-foot building, scheduled for completion in October 1989. That leaves $\$ 35$ million as an endowment for research support, which will provide about $\$ 1.5$ million in research funding each year. The institute's research costs are likely to be 10 times that amount, so most of the research will need to quickly become self-supporting with government grants.

The first round of proposals for resource centres was recently received by the six-member in-house faculty committee, and will be reviewed over the next few months. The 14 proposals include plans for ultrasensitive mass spectroscopy to be used for protein sequencing, and development of laser spectroscopy to study reactions on a femtosecond timescale, as well as Hood's facility.

Hood's proposal, frequently emphasized by Caltech during the fund-raising phase of the project, is almost certain to be among those chosen. It will require 10,000 square feet of space, says Hood, and at least $\$ 2$ million a year in operating funds, for which he is seeking support from the National Science Foundation. 